\title{
Study of the immunomodulating influence of preparation alpha/beta-defensins on chemo/radiotherapy of patients with oral and oropharyngeal cancer
}

\author{
H.A. Hirna ${ }^{1}$, D.V. Maltsev², L.V. Natrus ${ }^{2}$, M.M. Rozhko ${ }^{1}$, I.D. Kostyshyn ${ }^{1}$, \\ I.S. Tanasiychuk ${ }^{1}$ \\ ${ }^{1}$ Ivano-Frankivsk National Medical University, Ivano-Frankivsk; \\ ${ }^{1}$ Bogomolets National Medical University, Kyiv; e-mail: Lnatrus777@gmail.com
}

\begin{abstract}
The state of antitumor immunity of patients with oral cavity and oropharyngeal cancer during treatment (radiation and chemoradiation therapy), which additionally included $\alpha / \beta$-defensin immunotherapy, was studied. In all three study groups, where preparation $\alpha / \beta$-defensins was used, there was a more pronounced dose-dependent decrease in the relative number of lymphocytes in the blood than among those receiving cytostatic therapy in mono mode. Patients of group I received radiation therapy and immunotherapy, group II - chemoradiation and immunotherapy, group III - radiation therapy with immunotherapy in increased doses, VI - radiation, V-chemoradiation. Thus, in group I the decrease in the absolute number of lymphocytes was by $0.6 \times 10^{9} / l$, in group II - by $0.82 \times 10^{9} / l$, and in group III - by $0.93 \times 10^{9} / l$; by $8.51 \%$ there was a decrease in the relative number of lymphocytes in group I, by $15.52 \%$ in group II and in group III - by $14.32 \%$. A significant decrease in the absolute number of CD3+ T cells in the blood was registered with a combination of radiation-and immunotherapy: in group I from $1141 \times 10^{6} / \mathrm{l}$ to $682 \times 10^{6} / \mathrm{l}$ and in group III - from $871 \times 10^{6} / \mathrm{l}$ to $309 \times 10^{6} / \mathrm{l}$. At the same time, there was an increase in the relative number of natural killers in the blood of patients undergoing radiation therapy in combination with immunotherapy, also with a dose-dependent effect, the growth in group I is from 16 to $17 \%$ and group III - from 13.4 to $19.5 \%$. Among patients undergoing cytostatic therapy, there were significant differences in the absolute number of NKT cells in the combination of radiation and immunotherapy, groups I and III, by reducing the number of these lymphocytes in the blood from 86 to 57 and from 62 to 31, respectively. $\alpha / \beta$-defensins have been shown to have a dose-dependent adjuvant effect on cytostatic treatment - radiation, and chemoradiation of patients with cancer of the oral cavity and oropharynx. Simultaneously with the use of the drug $\alpha / \beta$-defensins associated additional immunomodulatory effect in the form of the restructuring of the subpopulation of lymphocytes due to an increase in the relative number of natural killers in the blood.
\end{abstract}

Key words: immunotherapy; immunomodulation; immunosuppression; adjuvant; natural killer Tlymphocytes; antitumor resistance.

\section{INTRODUCTION}

The development of effective and safe strategies for the treatment of malignant tumors of the oral cavity is an important task of modern medicine. Despite some progress in recent decades, these severe and rapidly progressing cancers are still a significant cause of premature death [1]. It is established that in patients with squamous cell carcinoma of the oral cavity and oropharynx occurs an immune imbalance, which includes a decrease in the absolute and relative content of $\mathrm{T}$ lymphocytes [2], the inadequate activity of natural killers (NK) [3], spontaneous apoptosis of cytotoxic T lymphocytes [4] and insufficiently effective antigen presentation [5]. This immune imbalance reduces the body's antitumor resistance, which also contributes to the faster progression of neoplasia. Existing immune dysfunction is intensified by immunosuppressive iatrogenic effects: radiotherapy and cytostatic chemotherapy, which are used to inhibit tumor growth [2].

The results of research show, that oncologic patients have increased the number of NK

(C) H.A. Hirna, D.V. Maltsev, L.V. Natrus, M.M. Rozhko, I.D. Kostyshyn, I.S. Tanasiychuk 
cells, which determines the adequate immune response to the tumor. According to data from recent studies, it was found that in patients with oropharyngeal cancer the blood content of CD45 $+\mathrm{CD} 3+\mathrm{CD} 16+\mathrm{CD} 56+\mathrm{NK}$ T-lymphocytes is increased by 1.6 times, and the number of CD45 + CD16 + NK cells is also significantly increased. The total number of CD $45+$ CD8 + lymphocytes expressing intracellular perforin $($ CD45 + CD8 + Perforin +$)$ and NK cells with the CD45 + CD16+ Perforin + phenotype significantly increases with tumor development, indicating an increase in the activity of the effective antitumor immune system. In particular, this is due to an increase in the subpopulation of effector cells with the CD45 + CD3-CD8 + phenotype on the background of a reduced number of CD45 + CD3 + CD4 + T-lymphocytes $[6$, 7]. With the growth of the oral and oropharyngeal tumors, the percentage of CD4 + and CD8 + T cells [8], CD4 + CD25 + T lymphocytes and CD4 + CD69 + cells increase. This is considered to be an adequate response because these cells initiate and regulate the antitumor immune response $[9,10]$.

Considering the above, a combination of traditionally used radiotherapy and cytostatic drugs with immunotropic agents, that would enhance the natural antitumor immune response, appears to be potentially useful to increase the effectiveness of antitumor therapy [6]. Currently, successful clinical trials of some immunotropic agents in oncology are conducted, in particular, interferons of different classes [11], recombinant interleukin 2 [12], and thymosin- $1 \alpha$ [13]. Another promising antitumor protein is the so-called $\alpha$ - and $\beta$-defensins - natural peptidesantibiotics that can mediate the destruction of foreign and own modified cells, as well as have a number of immunomodulatory effects that may be useful in the implementation of antitumor immune response in humans. In particular, Farin, et al. [14] have recently demonstrated that the release of defensins is an important component of the biological effects of gammainterferon, whose role in antitumor immunity is well known. Accordingly, Mei, et al. [15] in an experimental study showed that defensin-2 has an adjuvant effect on the immune response against melanoma and helps to slow the growth rate of tumor cells in vivo.

The antitumor properties of preparation $\alpha / \beta$ defensins, which can be realized by antigenic labeling of malignant tumors and activation of the immune mechanism of their rejection, are currently being actively discussed $[16,17]$. This immunotherapeutic agent induces polyclonal lymphocytes activation, increases the number of CD3 + CD16 + CD56 + T-lymphocytes and CD3-CD16 + CD56 + cells that exhibit NK properties, and also modulates the activity of macrophages. These data indicate the potential benefit of the use of this immunotherapy in the treatment of human malignancies [16, 17]. According to the results of previous studies, the effectiveness of this immunotherapeutic agent is pronounced in the treatment of breast cancer [18] and lymphoma [19]. However, there are currently no data from clinical trials examining the immunomodulatory effect of preparation alpha/beta-defensins in patients with squamous cell carcinoma of the oral cavity and oropharynx. So, the aim of the study was to evaluate changes in the number of CD3 + T-lymphocytes, natural killers, and natural killer T-lymphocytes in the blood of patients with oral and oropharyngeal cancer during the addition of the immunotherapeutic agent $\alpha / \beta$-defensins in standard radio- and chemoradiotherapy.

\section{METHODS}

97 patients with squamous cell oral and oropharyngeal cancer were treated. The division of patients into groups depended on the scheme of special treatment and additional prescription of immunotherapy of the $\alpha / \beta$-defensins preparation. The preparation of $\alpha / \beta$-defensins was developed by scientists of the research and production enterprise "RPE" (Kyiv), by proteolysis of proteins of animal origin. $\alpha / \beta$-Defensins, trigger mechanisms of antigen-specific anti-tumor 
humoral and cellular immunity. Registration certificate for the drug No. UA/3647/01/01 dated 06.04.2020. The clinical trial is approved by the Ethics Commission of Ivano-Frankivsk National Medical University, the research protocol No. 94/17 dated 16.11.2017. The work is a fragment of research work of the Department of Dentistry of the Institute of Postgraduate Education of Ivano-Frankivsk National Medical University "Clinical effectiveness of complex treatment of dental and periodontal diseases in the population of environmentally unfavorable regions", state registration number $0118 \mathrm{U} 004144$.

Group I included 25 patients who received radiotherapy and immunotherapy with preparation $\alpha / \beta$-defensins (RT-Im), and group II included 20 patients who received chemoradiotherapy and immunotherapy (C/RT-Im). Immunotherapy regimen: $2.0 \mathrm{ml}$ twice a day intramuscularly 2 days before the beginning of special treatment for 5 days and for the next 10 days once a day $[16,19]$. Group III included 16 patients who received radiotherapy and immunotherapy with $\alpha / \beta$-defensins in an increased dose - $2 \mathrm{ml}$ intramuscularly twice a day for the first 10 days, and then another 10 days once a day (RT-2Im). Group IV included 20 patients who received only remote gamma therapy (RT), and Group V - 16 patients who received radiotherapy and chemotherapeutic potentiation (C/RT).

Radiotherapy of oral and oropharyngeal cancer was performed up to a total dose of 36-40 Gy (SD - 2-2.5 Gy, 5 sessions a week) on the device «Cobalt-60» in KNPE «Carpathian Clinical Oncology Center» of Ivano-Frankivsk Regional Council. Chemotherapeutic potentiation was performed regionally, through the superficial temporal or external carotid artery. Intra-arterial potentiation was performed with cisplatin SD 20 $\mathrm{mg} / \mathrm{m}^{2}$ for 5 days after radiotherapy [20].

Among all patients, 12 are women and 85 are men, which is 13 and $87 \%$, respectively. By age, the distribution was as follows: $11(11.3 \%)$ patients aged 41-50 years, $44(45.4 \%)$ patients were 51-60 years old, 30 (30.9\%) patients aged $61-70$ years, $8(8.3 \%)$ patients in the age group
$71-80$ and $3(3.1 \%)$ were $81-85$ years old. 1 $(1.0 \%)$ patient was 33 years old. $84(86.6 \%)$ patients excessively abused alcohol during their lifetime and $78(80.4 \%)$ were chronic smokers.

From the anamnesis, it is known that 2 $(2.1 \%)$ patients had chronic trauma with carious teeth of the oral mucosa and $5(5.2 \%)$ - dental prostheses.

According to the table 1 most patients had a tumor of the oropharynx and in stage III, the distribution among the groups was as follows: in group I - 12 patients (48\%), in group II twice less - $6(30 \%), 7(44 \%)$ patients in group III, 8 $(40 \%)$ - group IV and $4(25 \%)$ - V. With tongue cancer most patients were also in stage III, it is 17 out of 21 . Analyzing the distribution among the groups, the largest number of patients with tongue cancer was in group II - $9(45 \%)$, then 7 $(44 \%)$ in V and $3(15 \%)$ in IV and only 1 patient in each I and III groups. Among all patients, the tumor of the bottom of the mouth was in 27 patients, 15 - lateral and 12 - frontal. In group I there were $3(12 \%)$ patients with lateral cancer, in groups II and IV there were $4(20 \%)$ and 3 $(19 \%)$ patients in group III. $4(16 \%)$ patients with squamous cell carcinoma of the frontal part of the oral cavity were in group I, 1 patient - in groups II and III, in IV and V there were slightly more - 3 patients in each. With cancer of the mucous membrane of the alveolar process of the low jaw, there were 2 patients in groups I and III, and 1 patient in group IV. One patient was in groups I, III, IV with cancer of the mucous membrane of the retromolar area and 1 patient of the same group with cancer of the hard palate. 1 (4\%) patient of group I had cancer of the mucous membrane of the alveolar process of the upper jaw and $1(6 \%)$ patient of group $\mathrm{V}$ - cancer of the buccal mucosa.

In all patients of the study, the diagnosis of cancer was confirmed morphologically. During processing the biopsy material, squamous cell carcinoma G1 in group I was verified in $8(32 \%)$ patients and $5(25 \%)$ patients of groups II and IV, $4(25 \%)$ and $6(38 \%)$ patients in groups III and $\mathrm{V}$, respectively. G2 had $10(40 \%)$ patients 


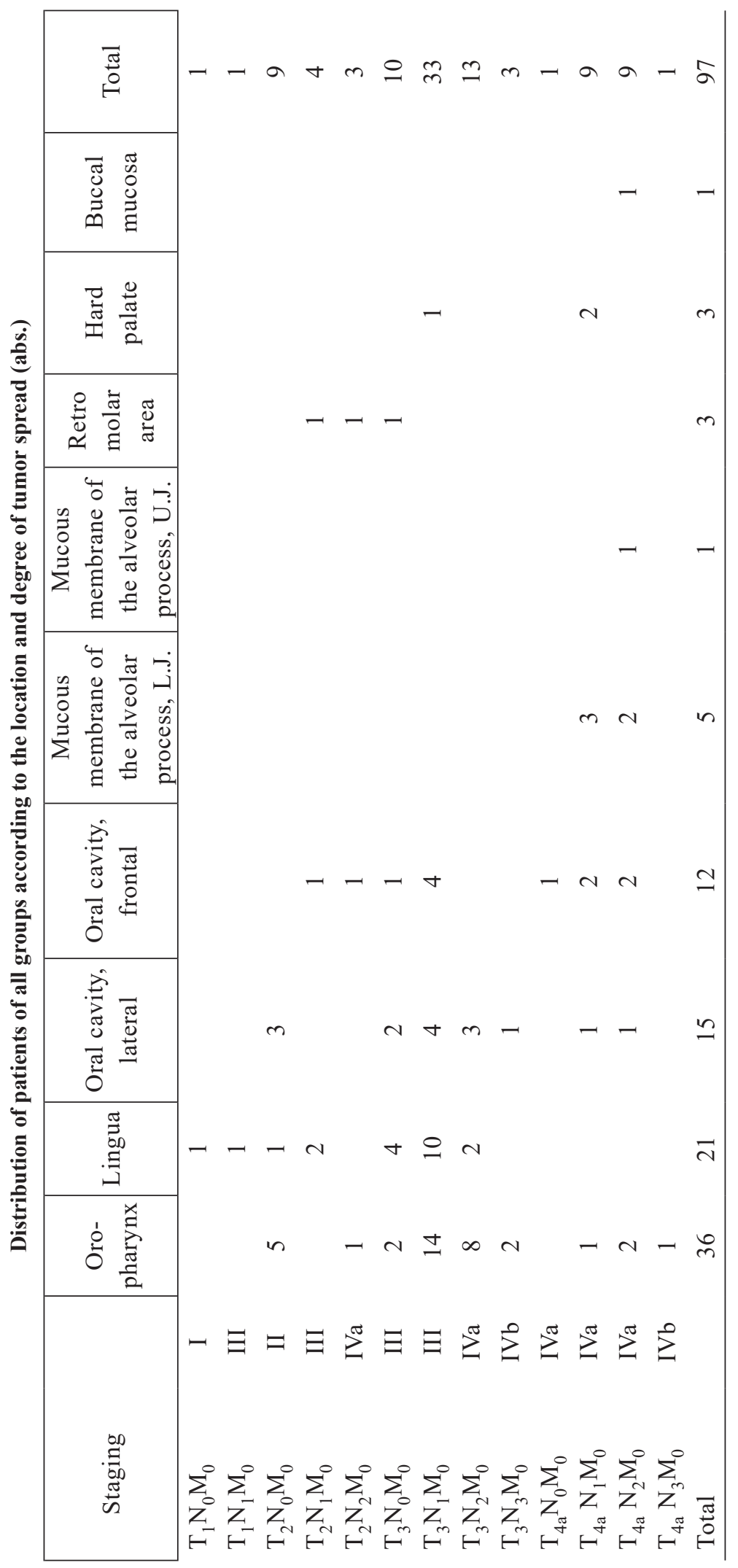


in group I, $11(55 \%)$ - group II, $13(65 \%)$ - IV and $8(50 \%)$ - groups III and V. Squamous cell carcinoma with G3 differentiation had $7(28 \%)$ patients in group I, $4(20 \%)$ - group II and 4 $(25 \%)$ - group III and 2 patients, respectively, 10 and $12 \%$ were in groups IV and V.

The exophytic form of growth was in the smallest number among all patients: so, in I, II and III groups one patient in each, 3 (15\%) - in IV and $2(13 \%)$ - in V group. Endophytic form of tumor growth was detected in $16(64 \%)$ patients in group I, 14 (70\%) patients in group II, 11 (69 and 55\%) - in groups III and IV, and $9(56 \%)$ - in V. Mixed form of tumor growth was in $8(32 \%)$ patients in group I, slightly less in group IV - 6 $(30 \%), 5$ patients in groups II and V, it is $25 \%$ and $31 \%$, respectively, and the least - 4 (25\%) in group III.

The assessment of the systemic cellular antitumor immunity in the patients' blood was determined by the number of CD3 + (T lymphocytes); CD3-CD16 + CD56 + (natural killers, NK cells); CD3 + CD16 + CD56 + (natural killer T lymphocytes, NKT cells) using a set of monoclonal antibodies CD3-FITC / CD $(16+$ CD56) with a single and triple label to CD markers of lymphocytes produced by IOTest. Cell identification was performed by indirect immunofluorescence, and cell counting was performed using an "Epics XL" (USA) laser flow cytofluorimeter based on the laboratory of immunology and molecular biology of the Research Institute of Experimental and Clinical Medicine in Bogomolets National Medical University. Laboratory tests were performed before treatment in all patients and after completion of immunotherapy. On average, immunotherapy in the study groups was completed at a dose of $20 \mathrm{~Gy}$, and at the same dose of treatment were determined the blood parameters of patients in the comparison group.

Statistical analysis of the results was performed using the IBM SPSS Statistics 23. The verification of the distribution was performed using the Shapiro-Wilk test. Most parameters did not reflect the normal distribution, so we used nonparametric criteria: Kruskal-Wallis, for pairwise comparison we used the Dunn or Mann-Whitney test, taking into account the Bonferonni adjustment. Differences in the groups were indicated in the form of $\mathrm{P}$ with the indication of the significance level. $\mathrm{P}<0.05$ was assumed as statistically significant. To describe the data in the groups, the values of the median (Me) were given. The diagrams were provided in the form of columns with the indication (CI 95\%).

\section{RESULTS AND DISCUSSION}

Variation analysis of the results obtained in the study groups revealed, that both the applied radio- and chemoradiotherapy led to a decrease in the number of leukocytes in the blood, while the addition of preparation $\alpha / \beta$-defensins registered some increase in the number of leukocytes in the blood in all three study groups (Fig. 1A). These data suggest an immunomodulatory effect of preparation $\alpha / \beta$-defensins, which appears to have a certain cytoprotective effect on some subpopulations of white blood cells during immunosuppressive effects in patients with oral and oropharyngeal cancer. There were no differences in the cytoprotective effect of preparation $\alpha / \beta$-defensins in study groups I and III, which does not allow us to speak about the dose-dependent nature of the achieved effect.

Concerning the number of lymphocytes, the opposite dynamics were observed here. As expected, radio- and chemoradiotherapy led to immunosuppression, which was based on a decrease in the relative number of lymphocytes in the blood, as demonstrated by the results of study groups IV and V (Fig. 1C). This effect is the result of the well-known extended cytostatic effect of such therapeutic interventions. However, in all three study groups, where preparation $\alpha / \beta$-defensins was used, there was a more pronounced decrease in the relative number of lymphocytes in the blood than among those receiving cytostatic therapy 

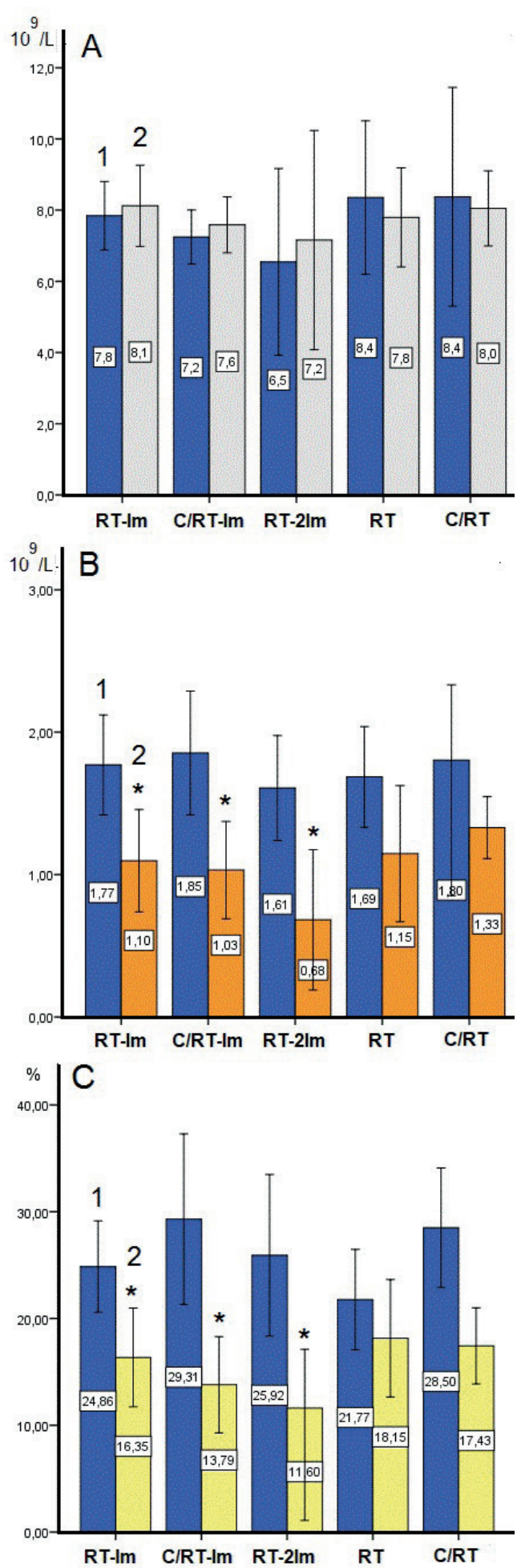

Fig. 1. Distribution of peripheral blood cells in patients of the study groups before (1) and after (2) treatment. A - blood leukocytes, B - the absolute number of lymphocytes, $\mathrm{C}$ - the relative number of lymphocytes. $* \mathrm{P}<0.05$
$(\mathrm{P}<0.05)$. A higher dose of preparation $\alpha / \beta-$ defensins led to a more pronounced decrease in the relative number of lymphocytes in the blood. This indicates the implementation of a dose-dependent effect with an increase of active substance of the immunotropic agent. Similar probable changes were observed in the absolute number of lymphocytes in the blood in study groups I, II, and III compared with groups IV and V $(\mathrm{P}<0.05)$. Also, the abovementioned dose-dependent effect was detected with deeper lymphocytopenia at higher doses of immunotropic agent (Fig. 1B).

These effects can be explained by the potentiation of immunosuppressive therapies under the influence of preparation $\alpha / \beta$-defensins the so-called adjuvant effect, well known in some immunotropic agents, tested in oncology in combination with cytostatic therapy. In particular, they are interferon $\alpha$-, $\beta$-, and $\gamma$, recombinant interleukin 2, colony-stimulating factors, and thymosin-1 $\alpha$ [11-13]. By biological nature, thymosin- $1 \alpha$ is the most similar immunotropic agent to the used immunotherapeutic agent preparation $\alpha / \beta$-defensins. In particular, Du D. and colleagues have recently demonstrated, that immunotherapy with thymosin-1- $\alpha$ increases the effectiveness of stereotactic radiotherapy in squamous cell carcinoma of the esophagus [13]. Accordingly, Zhou and colleagues [21] showed that the addition of thymosin- $\alpha$ to the therapy with Sirolimus reduces the risk of hepatocellular carcinoma recurrence in patients, who have undergone liver transplantation.

In examining the dynamics of the relative number of CD3 + T-lymphocytes in the blood in the study groups (Fig. 2A) there was a decrease in the number of lymphocytes of this subpopulation in patients undergoing chemotherapy with the addition of preparation $\alpha / \beta$-defensins. At the same time, in the case of radiotherapy, there was some decrease in the immunosuppressive effect of radiation at a lower dose of preparation $\alpha / \beta$ defensins and the disappearance of this effect with increasing dose of immunotropic agent. The results of the absolute number of $\mathrm{CD} 3+$ 

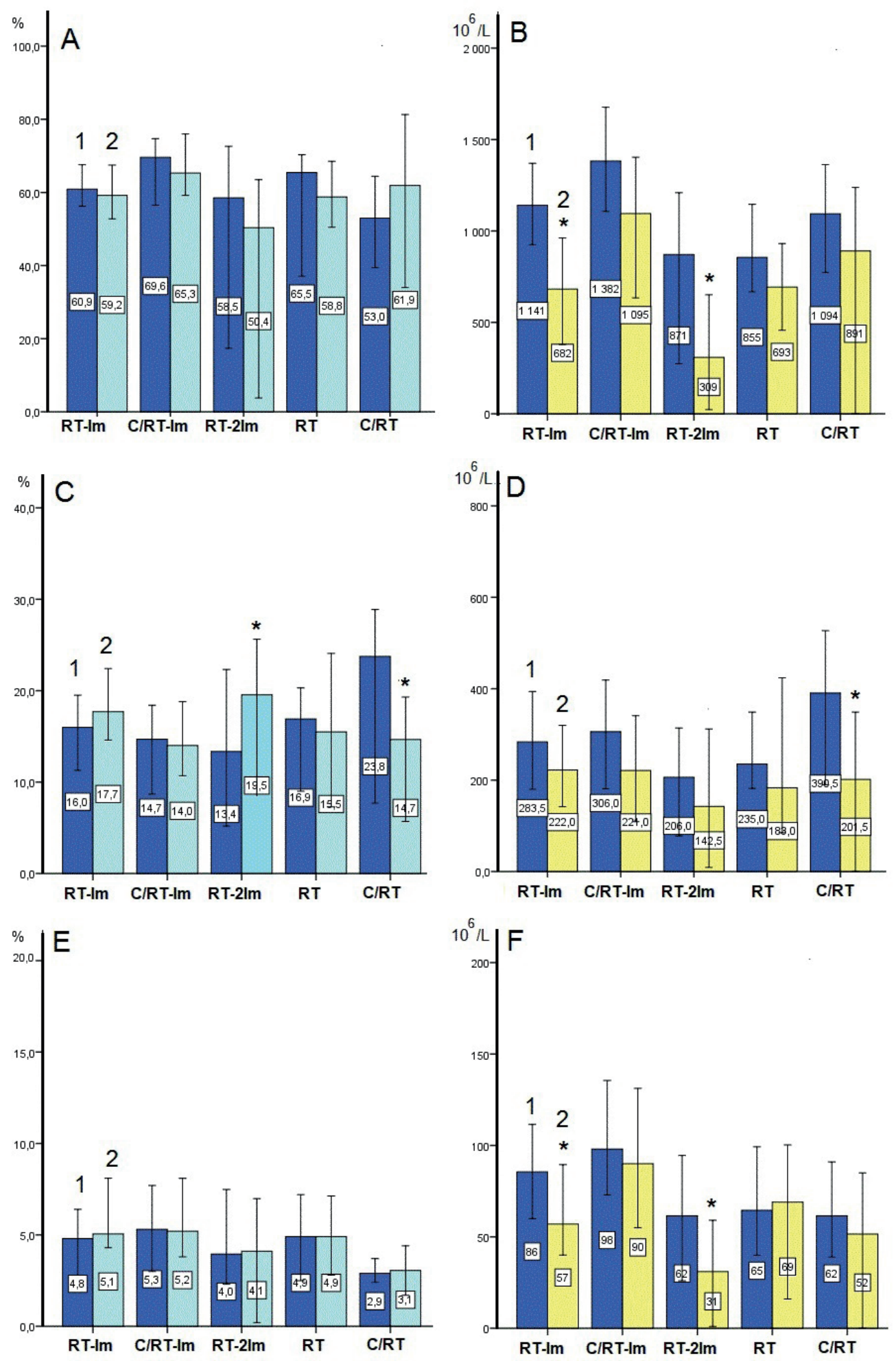

Fig. 2. Peripheral blood cell division in patients of the study groups before (1) and after (2) treatment. A - relative number of T lymphocytes, B - absolute number of T lymphocytes, $\mathrm{C}$ - relative number of natural killers, D - absolute number of natural killers, F - relative number of natural killer T lymphocytes, and $\mathrm{E}$ - absolute number of natural killer $\mathrm{T}$ lymphocytes. $* \mathrm{P}<0.05$ 
T-lymphocytes analysis in the blood in the study groups showed more significant changes (Fig. 2B). A probable decrease in the absolute number of CD3 + T cells in the blood was registered in study groups I and III $(\mathrm{P}<0.05)$. There was a slight decrease in the absolute number of CD3 + $\mathrm{T}$ cells in the blood when using chemotherapy in the group of preparation $\alpha / \beta$-defensins. A more pronounced decrease in the absolute number of this subpopulation of lymphocytes was observed in the blood when using preparation $\alpha / \beta$ defensins in patients undergoing radiotherapy with a demonstration of the dose-dependent effect (a deeper decrease in the absolute number of CD3 + T lymphocytes in the blood when using a higher dose of immunotropic agent). The obtained data can also be explained by the strengthening of cytostatic effects of antitumor treatment under the influence of preparation $\alpha / \beta$-defensins. This effect may be related to the more pronounced anticancer effects of both chemoradio- and radiotherapy under the influence of adjuvant (preparation $\alpha / \beta$ defensins).

There was an increase in the relative number of natural killers in the blood of patients undergoing radiotherapy in the case of taking preparation $\alpha / \beta$-defensins with a dose-dependent effect - with a probably larger increase in the relative number of natural killers in the blood in patients receiving a higher dose of immunotropic agent (Fig. 2C; $\mathrm{P}<0.05$ ). However, such dynamics were not observed among patients receiving chemoradiotherapy, as in both study groups there was a decrease in the relative number of natural killers in the blood during the clinical study, especially in group $\mathrm{V}$, where a significant difference was recorded $(P<0.05)$. At the same time, patients receiving preparation $\alpha / \beta$-defensins had a smaller decrease in the relative number of natural killers in their blood compared to those, receiving chemotherapy on a single regimen. The analytic results of the dynamics in the absolute number of natural killers in the blood show a decrease in the number of these cells in all study groups, which, most obviously, was the result of the immunosuppressive effect of cytostatic treatment (Fig. 2D).

However, patients receiving chemotherapy with the addition of preparation $\alpha / \beta$-defensins had a less pronounced reduction in the absolute number of natural killers in their blood than those, treated with chemotherapy alone (without immunotherapy). Such differences were not observed among patients receiving radiotherapy. These data indicate a certain rearrangement of the subpopulation composition of lymphocytes in patients receiving cytostatic treatments on the background of preparation $\alpha / \beta$-defensins use. According to the results of the combined analysis of the relative and an absolute number of natural killers in the blood in the study groups, a certain cytoprotective effect on NK cells was observed when using preparation $\alpha / \beta$-defensins.

This effect may be useful in the treatment of oral and oropharyngeal cancer, as NK cells are an important component of the natural antitumor cytotoxic immune response, which is implemented in cancer patients to prevent tumor growth [1]. Usually, cytostatic agents reduce the effectiveness of antitumor immune responses, which is an undesirable effect of therapy. According to this analysis, preparation $\alpha / \beta$-defensins is most likely to help in maintaining the number of natural killers when using cytostatic therapy in patients with oral and oropharyngeal cancer. It seems to be a potentially useful feature given the possibility of increasing antitumor resistance of the patient. The deficiency of natural killers in the human body dramatically reduces antitumor resistance and contributes to tumor growth. In particular, cervical carcinoma [22], haemophagocytic lymphohistiocytosis [23], metastatic melanoma [24], Hodgkin's lymphoma [25], and adrenal smooth muscle tumors [26] have been reported in patients with selective deficiency of natural killers. At present, methods of treating malignant neoplasms with so-called lymphokine-activated natural killers, called NK-cell therapy [27], are being actively tested in clinical practice. 
According to the results of the study, natural killer T-lymphocytes, although they have many common features with natural killers and perform a number of similar functions in the immune system of the human body, respond differently to preparation $\alpha / \beta$-defensins immunotherapy during cytostatic interventions for malignant neoplasms of the oral cavity and oropharynx. The relative number of NKT cells in the blood did not show significant dynamics in the study groups depending on the addition of immunotherapy with preparation alpha/betadefensins. But the absolute number of natural killer T-lymphocytes in the blood among patients undergoing radiotherapy decreased in the study groups with preparation $\alpha / \beta$-defensins addition with a dose-dependent manner (deepening of cell deficiency in patients receiving a higher dose of immunotropic agent) (Fig. 2F). Among patients undergoing cytostatic therapy, there were significant differences in the absolute number of NKT cells in the blood in study groups I and III due to a decrease in the number of these lymphocytes in the blood $(\mathrm{P}<0.05)$ (Fig. 2E). These data correspond to the results of the analysis of CD3 + T lymphocyte's absolute number in the blood of the study groups. It seems obvious that the use of preparation alpha/beta-defensins was associated with an enhancement of the immunosuppressive effect of the applied radiation treatment on natural killer $\mathrm{T}$ cells, similarly as was observed on $\mathrm{CD} 3+\mathrm{T}$ lymphocytes.

\section{CONCLUSIONS}

1. The preparation $\alpha / \beta$-defensins has an adjuvant effect on both cytostatic therapeutic agents radiation- and chemoradiotherapy - with a more pronounced effect on radiotherapy in patients with oral and oropharyngeal cancer. This effect is dose-dependent.

2 . The preparation $\alpha / \beta$-defensins has an additional immunomodulatory effect with a certain rearrangement of the subpopulation of blood lymphocytes. Probably it is associated with the achievement of cytoprotection against natural killers and indicates at least partial preservation of the cellular cytotoxic immune response against the tumor during treatment.

3 . The use of an immune agent - preparation $\alpha / \beta$-defensins allows to achieve better results with a more favorable tolerability profile of standard antitumor therapy.

Ethics statement. All patients, whose blood was received for the study, gave permission in the form of written informed consent for the usage of biological material for the study. The Ethics Commission of Ivano-Frankivsk National Medical University approved the research protocol (protocol No. 94/17 dated 16.11.2017).

Funding. The study was partially funded by the Ministry of Health of Ukraine, No. tate registration $0121 U 107940$.

The authors of this study confirm that the research and publication of the results were not associated with any conflicts regarding commercial or financial relations, relations with organizations and/or individuals who may have been related to the study, and interrelations of co-authors of the article.

\section{Г.А. Гирна, Д.В. Мальцев, Л.В. Натрус, М.М. Рожко, И.Д. Костышин, И.С. Танасийчук ИЗУЧЕНИЯ ИММУНОМОДУЛИРУЮЩЕГО ВЛИЯНИЯ ПРЕПАРАТА А/В-ДЕФЕНЗИНОВ НА ФОНЕ ХИМИОЛУЧЕВОЙ ТЕРАПИИ БОЛЬНЫХ РАКОМ ПОЛОСТИ РТА И РОТОГЛОТКИ}

Изучено состояние противоопухолевого иммунитета больных раком ротовой полости и ротоглотки при лечении (лучевая и химиолучевая терапия) которым дополнительно была включена иммунотерапия препаратом $\alpha / \beta$-дефензины. Пациентов разделили на 5 групп: I группа получала лучевую терапию и иммунотерапию, II - химиолучевую и иммунотерапию, III - лучевую с иммунотерапией в увеличенной дозе, VI - лучевую, V химиолучевую. Во всех группах наблюдения, применение препарата вызывало существенное снижение относительного и абсолютного количества лимфоцитов в крови, по сравнению с пациентами, получавшими цитостатическую терапию в монорежиме, причем отмечался дозозависимый 
эффект. Выявлено, что в I группе снижение абсолютного количества лимфоцитов на $0,6 \times 10^{9} /$ л, у II - на $0,82 \times 10^{9} /$ л и III - на $0,93 \times 10^{9} /$ л; на $8,51 \%$ было снижение относительного количества лимфоцитов в I группе, на $15,52 \%$ у II и в III группе - на $14,32 \%$. Достоверное снижение абсолютного количества $\mathrm{CD} 3+\mathrm{T}$-клеток в крови зарегистрировано при комбинации лучевой и иммунотерапии: в І группе с 1141 до $682 \times 10^{6} /$ л и в III - от 871 до $309 \times 10^{6} /$ л. В то же время отмечался рост относительного количества естественных киллеров в крови у пациентов, проходивших лучевую терапию в комбинации с иммунотерапией, также с дозозависимым эффектом, т. е. рост показателей в I группе составляет от 16,0 к $17,7 \%$ и III группы - от 13,4 к 19,5\%. Среди пациентов, проходивших цитостатическую терапию, отмечены достоверные различия в абсолютном количестве NKT-клеток при комбинации лучевой и иммунотерапии (I и III группы) за счет снижения количества этих лимфоцитов в крови со значения 86 к 57 и 62 к 31 соответственно. Установлено, что препарат $\alpha / \beta$-дефензинов оказывает дозозависимый адъювантный эффект при цитостатическом лечении - лучевой и химиолучевой терапией у пациентов с раком ротовой полости и ротоглотки. С приемом этого препарата ассоциирован дополнительный иммуномодулирующий эффект в виде перестройки субпопуляционного состава лимфоцитов за счет роста относительного количества естественных киллеров в крови.

Ключевые слова: иммунотерапия; иммуномодуляция; иммуносупрессия; адъювант; естественные киллерные Т-лимфоциты; противоопухолевая резистентность.

\section{Г.А. Гірна ${ }^{1}$, Д.В. Мальщев ${ }^{2}$, Л.В. Натрус ${ }^{2}$, М.М. Рожко ${ }^{1}$, І.Д. Костишин ${ }^{1}$, І.С. Танасійчук ${ }^{2}$ \\ ВИВЧЕННЯ ІМУНОМОДУЛЮЮЧОГО ВПЛИВУ ПРЕПАРАТУ А/В-ДЕФЕНЗИНІВ ПРИ ХІМІОПРОМЕНЕВОМУ ЛІКУВАННІ ХВОРИХ НА РАК ПОРОЖНИНИ РОТА I РОТОГЛОТКИ}

${ }^{1}$ Івано-Франківський національний медичний університет;

${ }^{2}$ Наиіональний медичний університет імені

O.O. Богомольияя, Київ; e-mail:Lnatrus777@gmail.com

Досліджено стан протипухлинного імунітету хворих на рак ротової порожнини і ротоглотки при лікуванні (променева та хіміопроменева терапія) яких додатково було включено імунотерапію препаратом $\alpha / \beta$-дефензинів. Пацієнтів олзділили на 5 груп: I група отримувала променеву терапію та імунотерапію, II - хіміопроменеву та імунотерапію, III - променеву з імунотерапією у збільшеній дозі, IV - променеву, V - хіміопроменеву. У всіх трьох групах спостереження, де застосовувався препарат $\alpha / \beta$-дефензинів, відзначалося виразніше зниження відносної кількості лімфоцитів в крові, ніж серед осіб, що отримували цитостатичну терапію у монорежимі, також був дозозалежний ефект. Так, у I групі зниження абсо- лютної кількості лімфоцитів було на $0,6 \times 10^{9} /$ л, у II - на $0,82 \times 10^{9} /$ л і III - на $0,93 \times 10^{9} /$ л; на $8,51 \%$ було зниження відносної кількості лімфоцитів в I групі, на $15,52 \%$ у II і в III групі - на 14,32\%. Вірогідне зниження абсолютної кількості CD3 + Т-клітин у крові зареєстровано при комбінації променевої і імунотерапії: I група з 1141 до $682 \times 10^{6} /$ л і III - від 871 до $309 \times 10^{6}$ /л. Водночас відзначалося зростання відносної кількості природних кілерів у крові пацієнтів, що проходили променеву терапію у комбінації з імунотерапією, також із дозозалежним ефектом, тобто підвищення значень показників I групи становить від 16 до 17\% і ІІІ групи - від 13,4 до 19,5\%. Серед пацієнтів, що проходили цитостатичну терапію, відзначено достовірні відмінності в абсолютній кількості NKT-клітин при комбінації променевої і імунотерапії, I і ІІІ групи, за рахунок зниження кількості цих лімфоцитів в крові 386 до 57 і 62 до 31 відповідно. Встановлено, що препарат $\alpha / \beta$-дефензинів чинить дозозалежний ад'ювантний ефект щодо цитостатичного лікування - променевої та хіміопроменевої терапії пацієнтів на рак ротової порожнини і ротоглотки. Разом 3 тим $з$ прийомом цього препарату асоційований додатковий імуномодулюючий ефект з перебудовою субпопуляційного складу лімфоцитів внаслідок зростання відносної кількості природних кілерів у крові.

Ключові слова: імунотерапія; імуномодуляція; імуносупресія; ад'ювант; природні кілерні Т-лімфоцити; протипухлинна резистентність.

\section{REFERENCES}

1. Maltsev DV, Girna GA. The deficiency of natural killer cells and/or natural killer T cells as the cause of malignancies (literature review). Clin Oncol. 2018; 8(1): 34-9.

2. Bron L, Jandus C, Andrejevic-Blant S, et al. Prognostic value of arginase-II expression and regulatory T-cell infiltration in head and neck squamous cell carcinoma. Int J Cancer. 2013; 132 (3): E85-93.

3. Dasgupta S, Bhattacharya-Chatterjee M, O'Malley JrBW, et al. Inhibition of NK cell activity through TGF-beta 1 by down-regulation of NKG2D in a murine model of head and neck cancer. J Immunol. 2005; 175: 5541-50.

4. Whiteside TL. Immunobiology of head and neck cancer. Cancer Metast. Rev. 2005; 24: 95-105.

5. Ferris R, Whiteside TL, Ferrone S. Clinical significance of down regulate dantigen processing machinery in head and neck cancer. Clin Cancer Res. 2006;12:3890-5.

6. Alcolea S, Anton R, Camacho M, et al. Interaction between head and necksquamous cell carcinoma cells andfibroblasts in the biosynthesis of PGE2. J Lipid Res. 2012; 53(4): 630-42.

7. Tsiklauri VT. Immunocorrective therapy in the complex treatment of patients with cancer of the mucous membrane of the oral cavity [author. dis...the degree candidate of Medical Sciences: 14.01.12]. Moscow: Russian Oncology Scientific Center named after NN Blokhin of the Russian Academy of Medical Sciences, 2013; 27 p. [Russian]. 
8. Whiteside TL. Tumor-induced death of immune cells: its mechanisms and consequences. Semin Cancer Biol. 2002;12(1):43-50.

9. Bron L, Jandus C, Andrejevic-Blant S, et al. Prognostic value of arginase-II expression and regulatory T-cellinfiltration in head and neck squamous cell carcinoma. Int J Cancer. 2013; 132(3): E85-93.

10. Loose D, Signore A, Bonanno E, et al. Prognostic value of CD25 expression onlymphocytes and tumor cells insquamous-cell carcinoma of the head andneck. Cancer Biother Radiopharm. 2008;23(1): 25-33.

11. Ni XR, Guo CC, Yu YJ, et al. Combination of levetiracetam and IFN-alpha increased temozolomide efficacy in MGMT-positive glioma. Cancer Chemother Pharmacol. 2020;86(6):773-82.

12. Dafni U, Michielin O, Lluesma SM, et al. Efficacy of adoptive therapy with tumor-infiltrating lymphocytes and recombinant interleukin-2 in advanced cutaneous melanoma: a systematic review and meta-analysis. Ann Oncol. 2019; 30(12):1902-13.

13. Du D, Song T, Dai H, et al. Stereotactic body radiation therapy and thymosin alpha-1-induced anti-tumor effects in heavily pretreated, metastatic esophageal squamous cell carcinoma patients. Oncoimmunology. 2018; 7(8): e1450128.

14. Farin HF, Karthaus WR, Kujala P, et al. Paneth cell extrusion and release of antimicrobial products is directly controlled by immune cell-derived IFN-gamma. J Exp Med. 2014;211(7):1393-405.

15. Mei HF, Jin XB, Zhu JY, et al. Beta-defensin 2 as an adjuvant promotes anti-melanoma immune responses and inhibits the growth of implanted murine melanoma in vivo. PLoS One. 2012; 7(2): e31328.

16. Zakharenko VV, Naishtetik VYa, Kudryavtseva IG, et al. Pharmacological properties of the drug propes (experimental studies) Oncology. 2004; 6(3):36-7. [Ukrainian].

17. Mamchur VI, Levykh AE. Defensins - endogenous peptides with anti-infective and anticancer properties (review). Tavricheskiy Med-Biol Vestn 2012; 15(58): 315-21. [Ukrainian].
18. Litvinenko AA. Implication of the immune correction in the complex treatment of breast cancer. Woman's health. 2012;1(67);134-7. [Ukrainian].

19. Sivkovich A, Gubareva AA, Pavlenko YuV, et al. Ways to improve the results of combined chemotherapy and radiation therapy in patients with malignant lymphomas. Med Business. 2005;7: 65-9. [Ukrainian].

20. Hirna HA, Kostyshyn ID, Rozhko MM, et al. Method of chemotherapeutic potentiation in radiation therapy of patients with oral cancer: Patent. 142686 Ukraina. No. u201911428; Declared. 25.11.2019; published. 25.06.2020, Bul. No. 12. 3 p. [Ukrainian].

21. Zhou L, Pan LC, Zheng YG, et al. Novel strategy of sirolimus plus thymalfasin and huaier granule on tumor recurrence of hepatocellular carcinoma beyond the UCSF criteria following liver transplantation: A single center experience. Oncol Lett. 2018;16(4): 4407-17.

22. Ballas ZK, Turner JM, Turner DA, et al. A patient with simultaneous absence of "classical" natural killer cells (CD3-, CD16+, and NKH1+) and expansion of CD3+, CD4-, CD8-, NKH1+ subset. J Allergy Clin Immunol. 1990; 85(2): 453-9.

23. Imashuku S, Hyakuna N, Funabiki T, et al. Low natural killer activity and central nervous system disease as a high-risk prognostic indicator in young patients with hemophagocytic lymphohistiocytosis. Cancer. 2002;94(11):3023-31.

24. Holtan SG, Creedon DJ, Thompson MA, et al. Expansion of CD16-negative natural killer cells in the peripheral blood of patients with metastatic melanoma. Clin Dev Immunol. 2011;2011:316314.

25. Machaczka M, Klimkowska M, Chiang SC, et al. Development of classical Hodgkin's lymphoma in an adult with biallelic STXBP2 mutations. Haematologica. 2013;98(5):760-4.

26. Shaw RK, Issekutz AC, Fraser R, et al. Bilateral adrenal EBV-associated smooth muscle tumors in a child with a natural killer cell deficiency. Blood. 2012;119(17):4009-12.

27. Rafei H, Daher M, Rezvani K. Chimeric antigen receptor (CAR) natural killer (NK)-cell therapy: leveraging the power of innate immunity. Br J Haematol. 2020. 20.

Received 20.07.2021 